\title{
IMPLEMENTASI SUBVERSION DAN REDMINE PROJECT MANAGEMENT DALAM PERANCANGAN TOKO KUE ONLINE
}

\author{
Xanty Adhi Parandani \\ Program Studi Manajemen Informatika \\ AMIK BSI Bogor \\ Email: xanty.parandani@gmail.com
}

\begin{abstract}
ABSTRAK
Belanja online telah menjadi gaya hidup konsumen saat ini. Kemudahan, mobilitas dan fleksibilitas menjadi daya tarik dari komponen e-commerce ini. Bagi penjual, metode penjualan via web merupakan salah satu metode yang sangat efisien, ekonomis dan efektif untuk meningkatkan omzet penjualan. Sebagai contoh kasus untuk penerapan konsep manajemen proyek, dibuat sebuahpurwarupa toko kue yang dirancang untuk sistem penjualan berbasis web (online). Purwarupa ini dibangun secara tim, dimana komponen dari situs ini dibuat secara terpisahpisah oleh masing-masing anggota tim. Dengan memanfaatkan fasilitas Subversion, partisi komponen sistem disatukan menjadi sebuah sistem yang utuh. Sebagai sebuah proyek sistem informasi yang dibangun secara tim, dibuat sistem pengaturan proyek menggunakan sebuah aplikasi manajemen proyek, Redmine Project Management. Redmine merupakan proyek manajemen berbasis web yang dibangun dengan bahasa Ruby diatas Framework Rail. Pembangunan web secara berkelompok dengan tugas individu mandiri akan sangat bermanfaat dalam mengembangkan kreativitas setiap individu, sehingga situs yang dihasilkan akan lebih unik, menarik dan easy fault tracing, karena mudahnya melacak letak dan penyebab kesalahan. Dari hasil kolaborasi menggunakan fasilitas Redmine dan Subversion, diperoleh sebuah situs toko kue online yang merupakan represntasi dari beragam gagasan anggota tim, namun bisa diintegrasikan dan berfungsi dengan baik, selayaknya situs yang dibuat secara individu.
\end{abstract}

Kata kunci: e-commerce, Tokokueku, Subversion, Redmine project management, ruby, framework rail.

\begin{abstract}
Online shopping has become a lifestyle of today's consumers. Convenience, mobility and flexibility are the main attraction components of e-commerce. For sellers, methods of selling via the web is one method that is highly efficient, economical and effective way to increase sales turnover.As an example the case for the application of project management concepts, created a prototype patisserie designed for web-based sales system (online).The prototype was built as a team, where the components of this site are made separately by each member of the team.By leveraging Subversion facility, the partition of system components together into a complete system. As a project information system is built as a team, created a project management system using a project management application, Redmine Project Management.Redmine is a web-based management project that was built with Ruby on Rail Framework. Web development in groups with independent individual tasks will be very helpful in developing the creativity of each individual, so that the site generated will be unique, attractive and easy fault tracing, as easy to track the location and cause of errors. From the result of collaboration using Redmine facilities and Subversion, obtained an online pastry shop which is a representation of the diverse ideas of team members, but can be integrated and functioning properly, such as sites created individually.
\end{abstract}

Keywords: e-commerce, Tokokueku, Subversion, Redmine project management, ruby, framework rail.

\section{PENDAHULUAN}

\subsection{Latar Belakang}

Pesatnya kemajuan teknologi internet, membuat sistem perniagaan yang awalnya berjalan secara konvensional (toko, kios, mall) bermigrasi atau setidaknya dibuat pula dalam bentuk sistem perniagaan elektronik (Electronic Commerce/E-Commerce). Electronic Commerce merupakan sebuah idiom yang menjadi domain istilah bagi seluruh sistem perniagaan dengan media elektronik, utamanya media internet. Layaknya perniagaan konvensional, perniagaan elektronik juga semakin sarat persaingan. Para pelaku pasar berlomba-lomba membuat "toko virtual" mereka menjadi semakin menarik dan lebih menarik dibandingkan pesaing sejenis. 
Tampilan yang atraktif, dinamis dan personal menjadi bagian penting dari sebuah situs e-commerce yang bisa menjadi situs eye-catching. Namun lebih dari pada itu, situs yang memiliki performa tinggi dalam kecepatan akses juga menjadi faktor penting bagi sebuah situs e-commerce agar ramai dikunjungi calon pembeli.

Pengembang situs harus mampu membangun situs dengan persyaratan minimum tersebut. Layaknya sebuah proyek yang bergantung pada sisi humanis (personal), maka perancangan sebuah situs web yang terbaik adalah secara tim (berkelompok), dimana setiap anggota tim akan mampu mengeksploitasi kemampuan individual mereka sesuai dengan bagian (part) dari sebuah situs secara keseluruhan. Namun, hal yang lebih penting lagi, sebuah situs web memiliki struktur sistem yang cukup rumit, sehingga apabila sistem tersebut dibangun secara berkelompok akan memiliki manfaat diantaranya:

a. Pengembangan/pembangunan sebuah situs web yang rumit, bisa lebih disederhanakan dengan membaginya menjadi komponen web yang lebih kecil (kegiatan/task bisa dibagi menjadi pengerjaan database, perancangan tampilan dan sistem interkoneksi)

b. Memasukkan "selera" yang berbeda-beda kedalam sebuah web, sehingga membuatnya lebih atraktif dan dinamis.

c. Easy Fault Tracing bisa dikatakan sebagai keunggulan dari sebuah sistem atau aplikasi yang dibangun secara tim, karena troubletracing (penelusuran kesalahan) dan kemudian langkah troubleshooting (perbaikan terhadap kesalahan), didalam sistem yang rumit akan menjadi lebih mudah karena tinggal menelusuri berdasarkan posisi kesalahan dan siapa anggota tim yang terlibat dalam merancang bagian yang mengalami kesalahan tersebut.

Dengan dilatarbelakangi oleh uraian tersebut, dikembangkan aplikasi toko kue online yang diberi nama "Tokokueku", dimana bisa disimulasikan ada seorang anggota tim menjadi project manager merangkap system developer, sedangkan anggota tim lainnya menjadi system developer.

Layaknya sebuah proyek yang melibatkan dua atau lebih personil anggota tim, dibutuhkan proses pengelolaan (management) dari proyek perancangan web dengan metode kerja tim ini. Disinilah pentingnya sebuah Information Technology Project Management.

\subsection{Landasan Teori}

\subsubsection{Subversion}

Subversion adalah sebuah sistem version control yang besifat gratis/opensource. Subversion mengelola sejumlah file dan directory dan kemudian melakukan perubahan terhadap file dan directory tersebut berulang-kali setiap dibutuhkan. Dengan Subversion ini, kita bisa melakukan recovery terhadap data-data versi lama atau memeriksa riwayat perubahan data yang pernah kita lakukan. Sehingga secara bebas, Subversion bisa diartikan sebagai sebuah "mesin waktu".

Subversion dapat beroperasi lintas jaringan, sehingga bisa digunakan oleh anggota tim pengembang yang menggunakan komputer-komputer berbeda (tentunya memungkinkan pula ketika komputerkomputer tersebut memiliki O/S berbeda, misal: Windows dan Linux). Pada tingkatan tertentu, peran Subversion akan sangat penting ketika anggota tim pengembang bisa melakukan kolaborasi dalam modifikasi dan pengelolaan sekumpulan data yang sama melalui Subversion ini. Jadi, pertanyaan tentang bagaimana sebuah tim pengembang (developer team) bisa bekerja sama secara efisien dalam membangun sebuah proyek, terjawab dengan adanya Subversion ini.

\subsubsection{Repository}

Inti dari sebuah sistem Subversion adalah Repository. Repository dapat diartikan sebagai pusat penyimpanan data didalam Subversion yang merupakan sistem terpusat untuk berbagi informasi [1]. Dalam gambar 1, diperlihatkan gambaran sederhana dari sistem server dan client. 


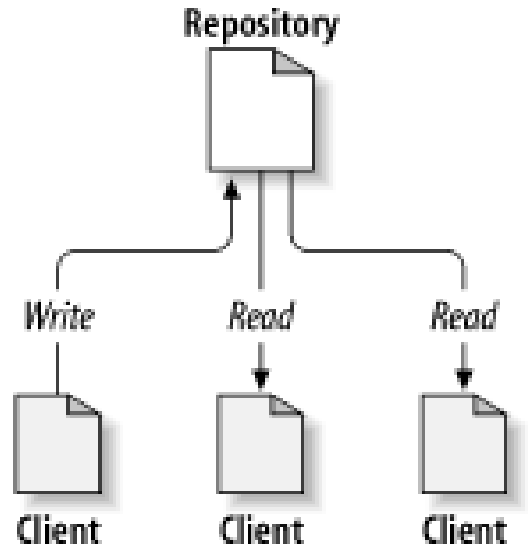

Gambar 1. Sistem Client dan Server [1]

Terlepas dari manfaat penting dari Subversiondan Repository, dalam pengelolaan data dibutuhkan pengawasan dari seorang team leader maupun setiap anggota tim dalam kaitan dengan siapa yang boleh membagi atau menerima informasi, dengan tentunya tidak menimbulkan tumpang tindih atau berhimpitnya data. Karena Subversion dengan kemampuan file sharing-nya bisa saja melakukan perubahan yang besar pada sistem ketika ada seorang anggota tim yang melakukan perubahan kecil pada bagian proyek yang ditanganinya.

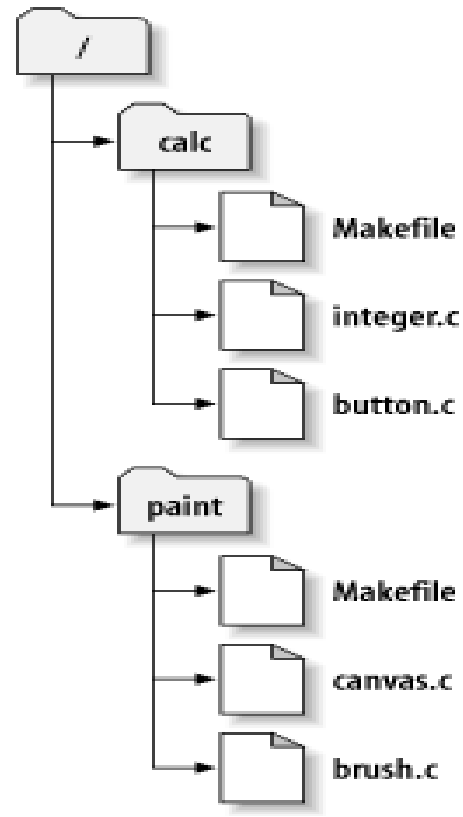

Gambar 2. Repository File System [1]

Didalam gambar 2 diatas, diperlihatkan bagaimana sistem penempatan file didalam sebuah Repository. komponen penyusun (files) dari sebuah calc(= aplikasi calculator) disimpan didalam directory calc, begitu pula dengan files penyusun paint (aplikasi menggambar) disimpan didalam directory paint. Sebuah tim pengembang bisa "berbagi tugas" berdasarkan files atau directories yang terdapat dalam sebuah proyek.

\subsubsection{Redmine}

Seperti yang telah disebutkan didalam bab sebelumnya, sebuah proyek yang dikerjakan secara tim atau kelompok mesti dikelola dengan baik untuk mengontrol kerja dan kinerja tim tersebut. Ada banyak perangkat yang bisa digunakan sebagai sarana Project Management. Redmine Project Management adalah sebuah tools pengelola proyek yang berbasiskan jaringan komputer. Redmine ditulis dengan bahasa pemrograman Ruby diatas Rail Framework. 
Redmine memiliki beberapa fungsi Project Management, diantaranya:

a. Mengatur pembagian kerja dalam sebuah proyek;

b. Mengatur jadwal dan rencana pengerjaan proyek;

c. Melacak setiap detail perubahan, pembaharuan, dan kerusakan yang mungkin terjadi di dalam proyek;

d. Melacak aktivitas setiap komponen yang terlibat didalam proyek dan perkembangan proyek

Redmine merupakan tool manajemen proyek yang dilengkapi dengan perangkat lunak pelacakan bug, dengan fokus pada kolaborasi, fungsi, dan ketika ditingkatkan dengan plugin tertentu, dapat dikonfigurasi secara aman untuk memfasilitasi proyek-proyek berorientasi keamanan[3].

\section{METODE DAN SISTEMATIKA PENELITIAN}

\subsection{Metode Penelitian}

Didalam penelitian ini terdapat serangkaian metode yang dilaksanakan untuk memperoleh hasil yang diharapkan, yaitu:

a. Observasi. Metode ini dilakukan untuk mengamati dan mempelajari fitur, kelebihan dan kekurangan dari website toko online yang mirip dengan toko online yang akan dirancang.

b. Studi Pustaka. Dilakukan untuk memperoleh panduan teoritis dan konfigurasi umum yang diperlukan untuk menyelesaikan rancang bangun website yang akan dikerjakan.

\subsection{Sistematika Penelitian}

Pada umumnya, manajemen proyek ini diperlukan untuk suatu proyek yang melibatkan banyak tugas (multitasking) dan melibatkan lebih dari satu orang. Akan tetapi, karena didalam penelitian ini hanya menitikberatkan pada implementasi Subversion dan Redmine, maka dilakukan simulasi hanya menggunakan beberapa komputer, akan tetapi pemrograman dilakukan secara individual. Perbedaannya dengan praktek nyata manajemen proyek terletak pada banyak orang yang terlibat dalam proyek saja. Simulasi yang dilakukan adalah sebagai berikut:

a. Satu komputer dijadikan sebagai server yang akan diinstalasi VisualSVN-Server-2.1.5. Server disimulasikan sebagai project manager.

b. Empat Komputer dijadikan sebagai client (yang akan diinstalasi TortoiseSVN-1.6.14.21012-x64-svn1.6.16. Client disimulasikan sebagai anggota-anggota tim (pelaksana proyek).

c. Pada masing-masing komputer client selanjutnya dilakukan pengembangan website sesuai dengan task masing-masing. Setiap pekerjaan yang dilakukan kemudian diperbaharui disisi server (project manager) maupun client (representasi dari anggota tim) yang lain.

d. Setelah setiap client menyelesaikan task masing-masing, maka disisi server dilakukan pemeriksaan hasil dan perbaikan kecil yang masih diperlukan.

e. Untuk melihat kinerja tim dan perkembangan proyek bisa diamati langsung dari server dengan menggunakan Redmine Project Management.

\section{PERANCANGAN SISTEM}

\subsection{Platform dan Database}

Aplikasi toko kue online "Tokokueku" ini dibuat dengan platform Content Management System (CMS) yang disediakan oleh Wordpress.Dengan pertimbangan CMS Wordpress cukup mudah diimplementasikan untuk aplikasi berbasis web. Subversion juga mampu menangani CMS Wordpress dengan sangat baik, sehingga kemungkinan terjadinya conflict ketika proses pengerjaan secara tim bisa diminimalisir. Namun, tidak menutup kemungkinan perancangan website ini bisa menggunakan bahasa pemrograman lain, seperti PHP dan Java

Untuk database, aplikasi ini menggunakan fasilitas yang tersedia di MySQL untuk penyimpanan dan pengelolaan database. Redmine merekomendasikan spesifikasi minimum bagi aplikasi yang dibangun, menggunakan Database Management System (DBMS) MySQL versi 5.0, PostgreSQL 8 atau SQLite 3. 


\subsection{Local Web Server}

Untuk menjalankan sistem ini pada konsol client dan konsol server, dibutuhkan web server lokal. Dalam aplikasi ini digunakan XAMPP Server, karena telah mendukung Apache dan MySQL. Pada gambar 3, diperlihatkan contoh penempatan aplikasi Tokokueku pada komputer di sisi client.

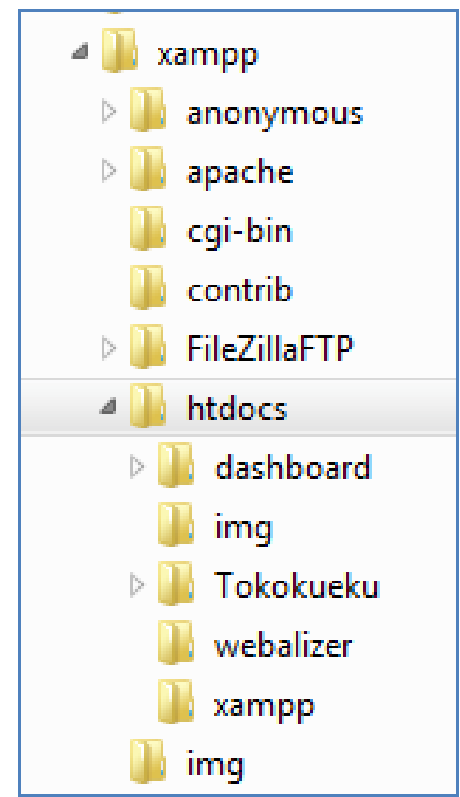

\section{Gambar 3. Penempatan Aplikasi pada Local Web Server}

\subsection{Instalasi Subversion}

Subversion yang dibutuhkan untuk membangun sebuah team-based project, terdiri atas dua sisi yaitu pada sisi Server (Project Manager) dan Client (anggota tim). Didalam proyek ini, pada sisi server digunakan VisualSVN-Server-2.1.5, sedangkan pada sisi Client digunakan TortoiseSVN-1.6.14.21012x64-svn-1.6.16.

Proses instalasi dilakukan sesuai prosedur instalasi standar, sehingga Subversion siap dijalankan dari komputer tempat instalasi dilakukan. Pada gambar 4 diperlihatkan hasil instalasi sistem Subversion pada sisi Client, ketika dilakukan proses kerja pada folder/directory aplikasi yang dibuat (sesuai nama directory yang dibuat masing-masing anggota tim).

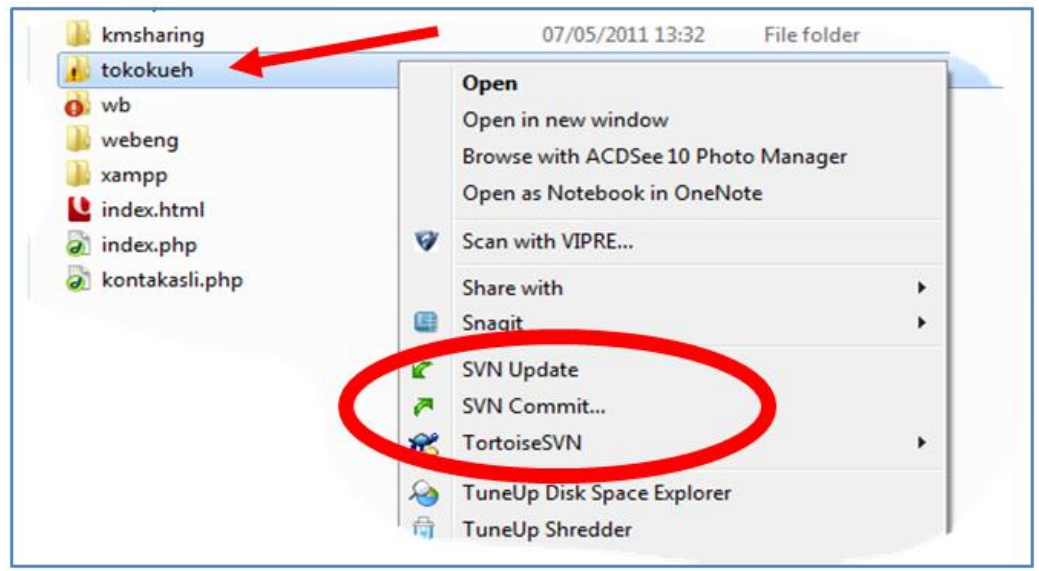

Gambar 4. Hasil Instalasi Subversiondi Sisi Client

Selanjutnya, aplikasi ini dikerjakan seperti bagan pada Gambar 5. 


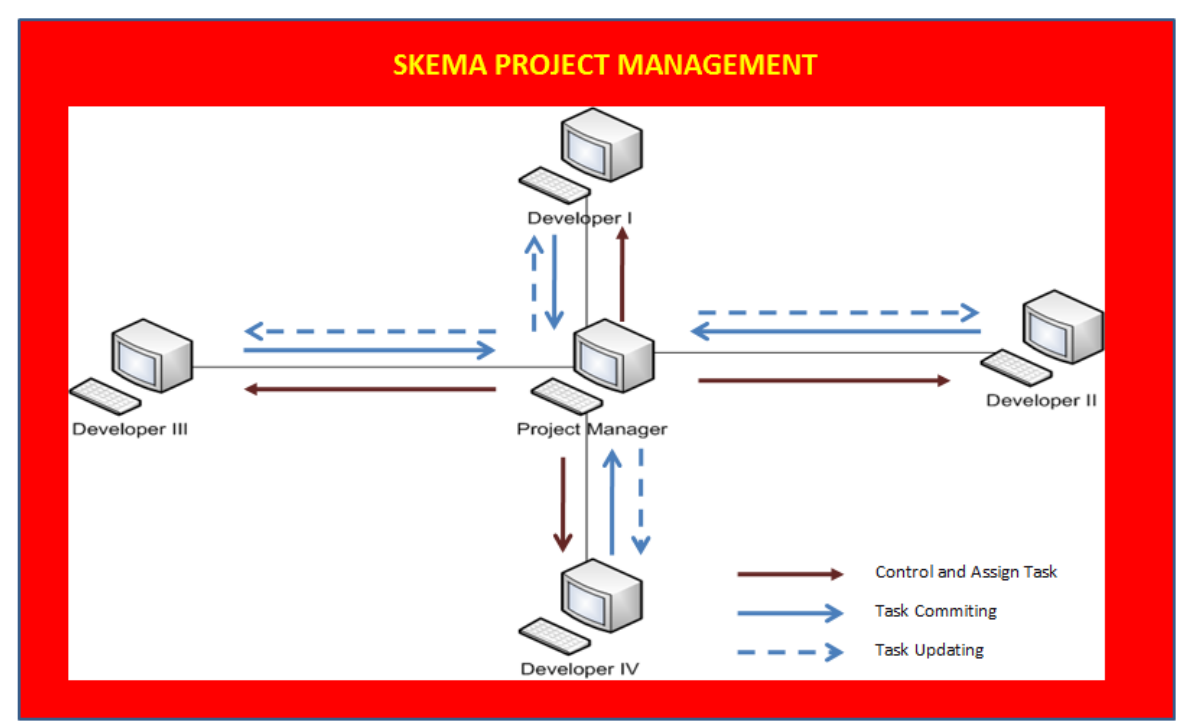

Gambar 5. Skema Project Management

Pada gambar 5 terlihat bagaimana skema pembagian dan pengontrolan tugas dilakukan oleh Subversion. Setiap anggota tim melakukan proses perancangan komponen sistem sesuai dengan pengaturan tugas dan kewenangan yang diatur oleh PM dengan menggunakan Redmine Project Management yang instalasi dan penggunaannya akan dijelaskan pada sub bab berikutnya. Setiap terjadi perubahan dan pembaharuan di sisi masingmasing Client (anggota tim), harus dilakukan proses commit (lihat gambar 4 dan gambar 5), yang artinya anggota tim yang melakukan perubahan atau pembaharuan bagian sistem sekecil apapun pada sisi Client juga harus diubah dan diperbaharui pula pada sisi Server (Project Manager). Kemudian supaya perubahan itu bisa dijalankan pada sisi anggota tim yang lain maupun pada sisi Server, maka masing-masing anggota tim yang lain harus melakukan proses update (lihat gambar 4 dan gambar 5).

\subsection{Project Management}

Sebagai seorang pengelola proyek, seorang Project Manager (PM) sudah bisa mengelola proyek yang dibawahinya. Untuk membuat atau menambahkan anggota tim, seorang PM bisa menambahkan anggota di jendela user, sesuai dengan kebutuhan tim untuk menyelesaikan proyeknya. Untuk contoh kasus website ini, 2 atau 3 orang sudah cukup untuk menyelesaikan proyek website ini. Untuk membuat atau menambahkan sebuah proyek baru, PM bisa melakukannya pada jendela project (gambar 6).

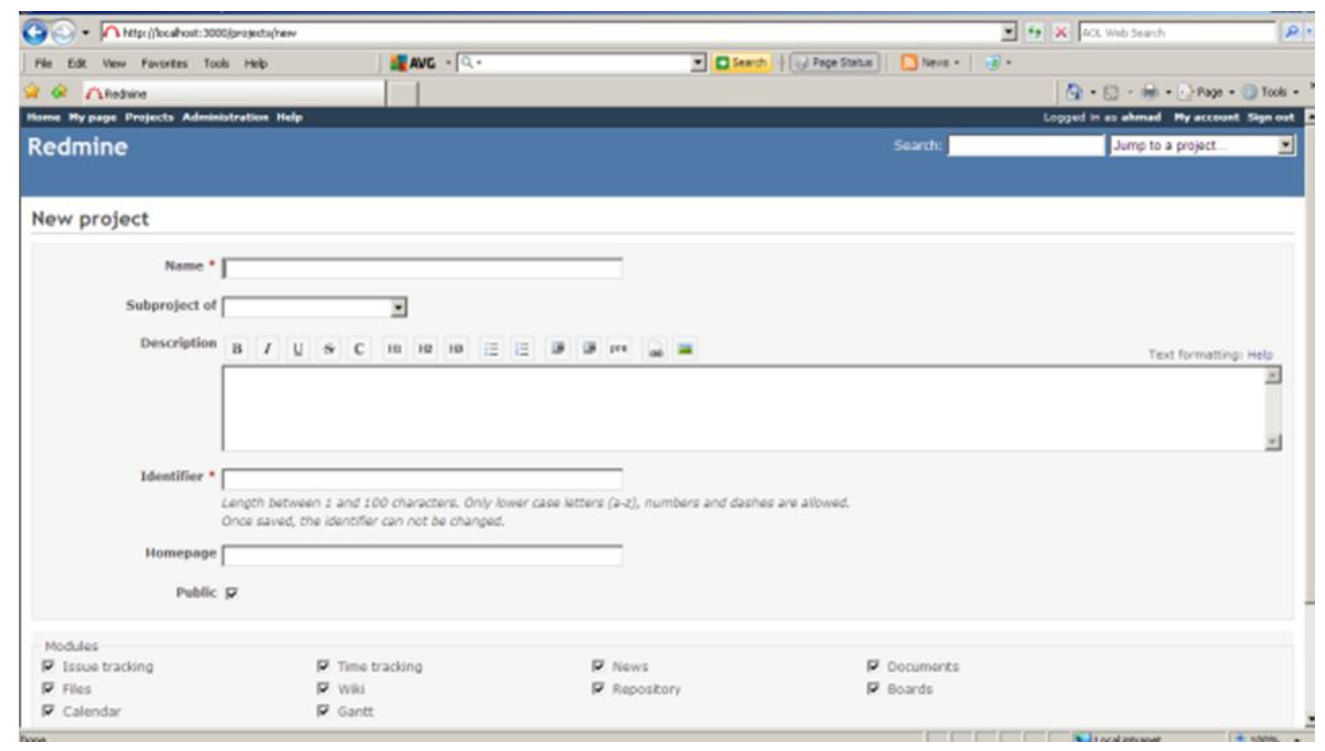

Gambar 6. Project Window 
Selanjutnya untuk menambahkan sub masalah atau rincian dari proyek yang dibangun, PM membuat pengaturannya pada form new issue (gambar 7).

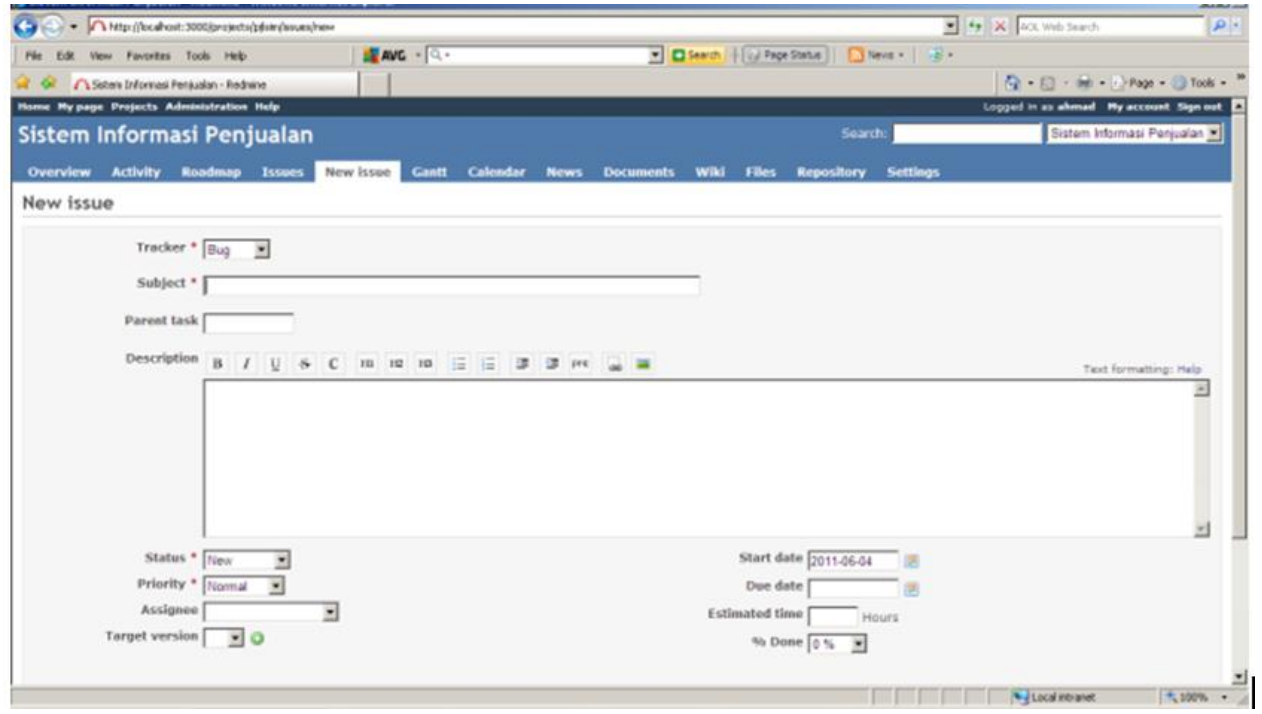

Gambar 7. Issue New Project (Sub Project)Window

Bagian yang sangat penting pada Redmine Project Management adalah sistem interkoneksi dengan Subversion dimana aplikasi tersebut dibuat atau dirancang. Pengaturan hal ini dilakukan pada jendela/form Setting $\rightarrow$ Repository. Proses penugasan, pengawasan dan pengontrolan proyek, bisa dilakukan oleh PM melalui form Sub Issue (per masalah).

Tugas yang sangat penting bagi seorang PM adalah pengawasan dan pengontrolan terhadap kinerja dan keberlangsungan sebuah proyek yang ditanganinya. Untuk menunjukkan seberapa jauh progress dari suatu proyek, model grafik adalah cara yang paling sering digunakan. Model grafis tersebut yang paling umum adalah Gantt Chart. Untuk Redmine, progress dan rincian dari setiap masalah dan issue bisa ditampilkan pada form/jendela Gantt (gambar 8)

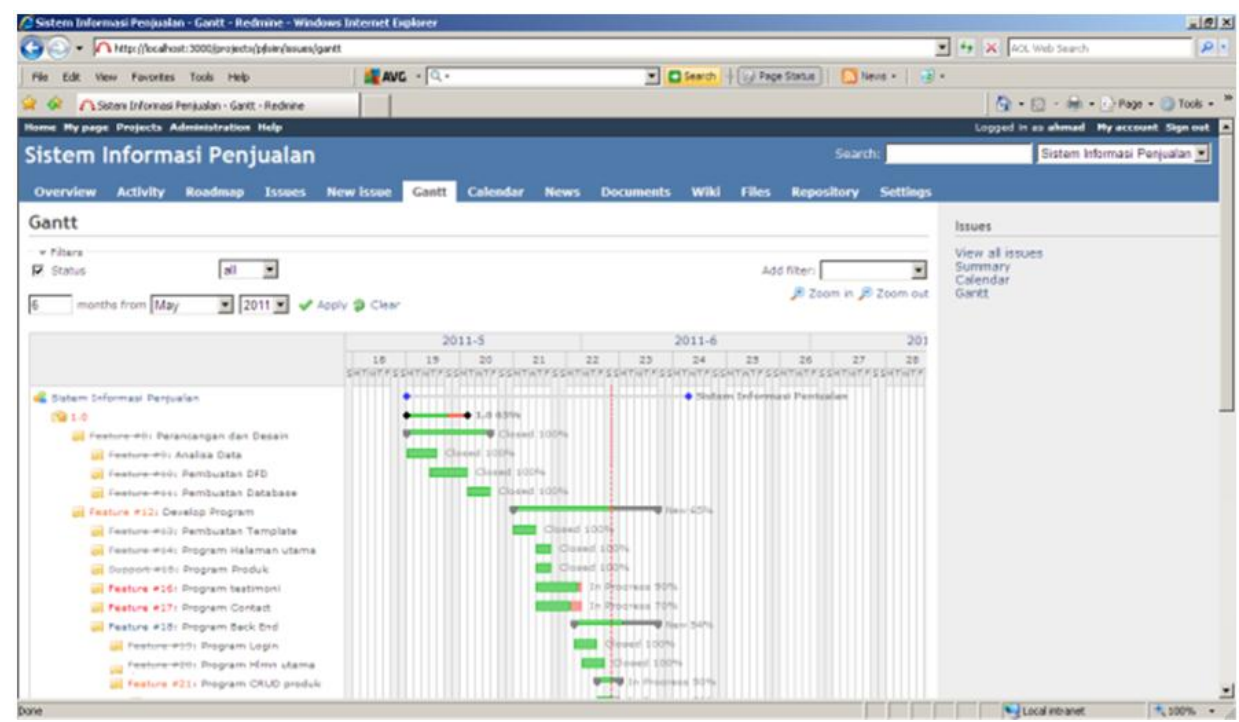

Gambar 8. Tampilan Gantt Chart

Sebagaimana disebutkan diawal, proyek "Tokokueku” adalah proyek yang dibangun secara berkelompok oleh beberapa orang developer. Sehingga perubahan dan perbaikan parts dari sistem ini menjadi issue yang sangat penting. Sehingga history dari proyek tersebut harus bisa ditampilkan secara rinci, seperti waktu perubahan, detail perubahan dan pelaku pengubahnya. Disamping itu, kinerja anggota tim bisa diawasi oleh PM, karena adanya data statistik lengkap dari hasil kerja setiap anggota tim. Untuk menggunakan fasilitas ini pada Repository sistem, Redmine menyediakannya pada form Repository $\rightarrow$ Root. 


\subsection{Use Case Diagram}

Sebuah diagram yang digunakan untuk menggambarkan apa saja aktifitas yang dilakukan oleh suatu sistem dari sudut pandang pengamatan luar atau sudut pandang end-user adalah definisi dari Use Case Diagram[4]. Sehingga, untuk menggambarkan proses atau aktivitas yang terjadi dalam penggunaan aplikasi toko kue online ini digunakan Use Case Diagram. Dalam Use Case Diagram yang ditampilkan pada Gambar 9 dapat dijelaskan perbedaan peran seorang konsumen (pembeli) umum dengan seorang karyawan (member). Untuk melihat isi situs terutama katalog kue yang dijual, seorang pembeli bisa melakukannya secara langsung, kemudian membeli kue yang diinginkan dengan melakukan pemesanan melalui telepon.

Untuk melakukan perubahan terhadap isi situs, hak akses (access grant) hanya diberikan kepada karyawan yang berhak dengan cara melewati proses $\log$ In terlebih dahulu. Setelah $\log$ In berhasil, karyawan (member) bisa melakukan perubahan terhadap isi situs diantaranya perubahan terhadap isi katalog, harga, kontak, perubahan testimoni dan pencetakan laporan.

Sebagai representasi penurunan atau pewarisan sifat (inheritance) pada konsep Object Oriented Analysis, karyawan bisa melakukan pembelian secara langsung, selayaknya konsumen biasa, dengan tanpa harus melakukan Log In terlebih dahulu.

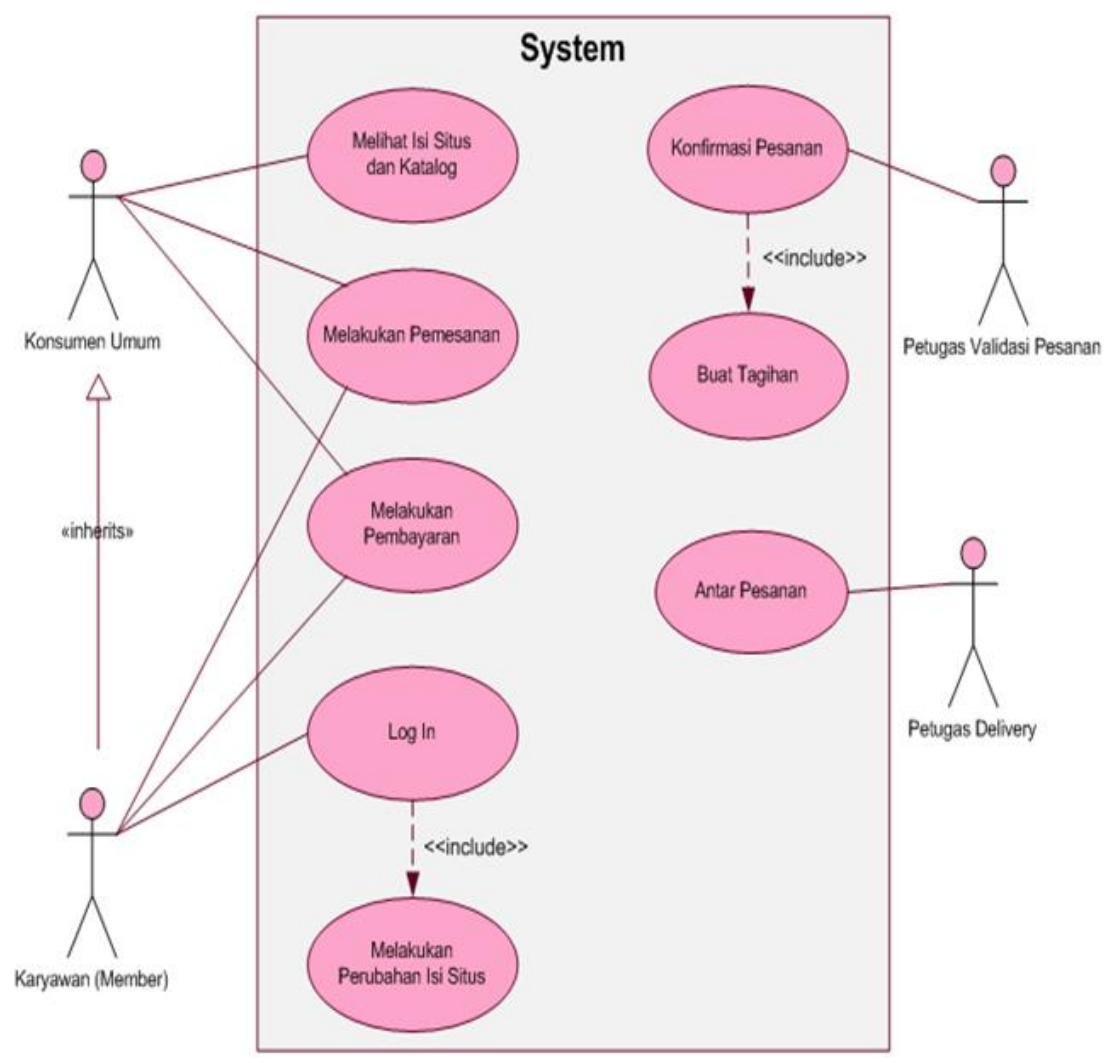

Gambar 9. Use Case Diagram

\section{ANALISA SISTEM}

Hasil dari proyek toko kue online ini, secara garis besar telah cukup baik. Hal ini ditinjau dari tujuan perancangan aplikasi ini yang dicoba untuk diimplementasikan dengan metode team work. Dengan metode ini, sebagaimana telah disinggung diawal tulisan bahwa tujuan yang diharapkan dari proyek ini adalah terciptanya sebuah online store yang memiliki kesan dinamis dan atraktif serta dibuat dengan kreasi seluruh anggota dari project developer team bisa diwujudkan. Dengan fasilitas Subversion yang dikontrol pula oleh Redmine Project Management ternyata sebuah proyek yang cukup kompleks seperti aplikasi toko online bisa diselesaikan dengan waktu relatif singkat dan pengerjaan yang lebih sederhana.

Pada gambar 10 diperlihatkan jendela utama dari website Tokokueku.. 


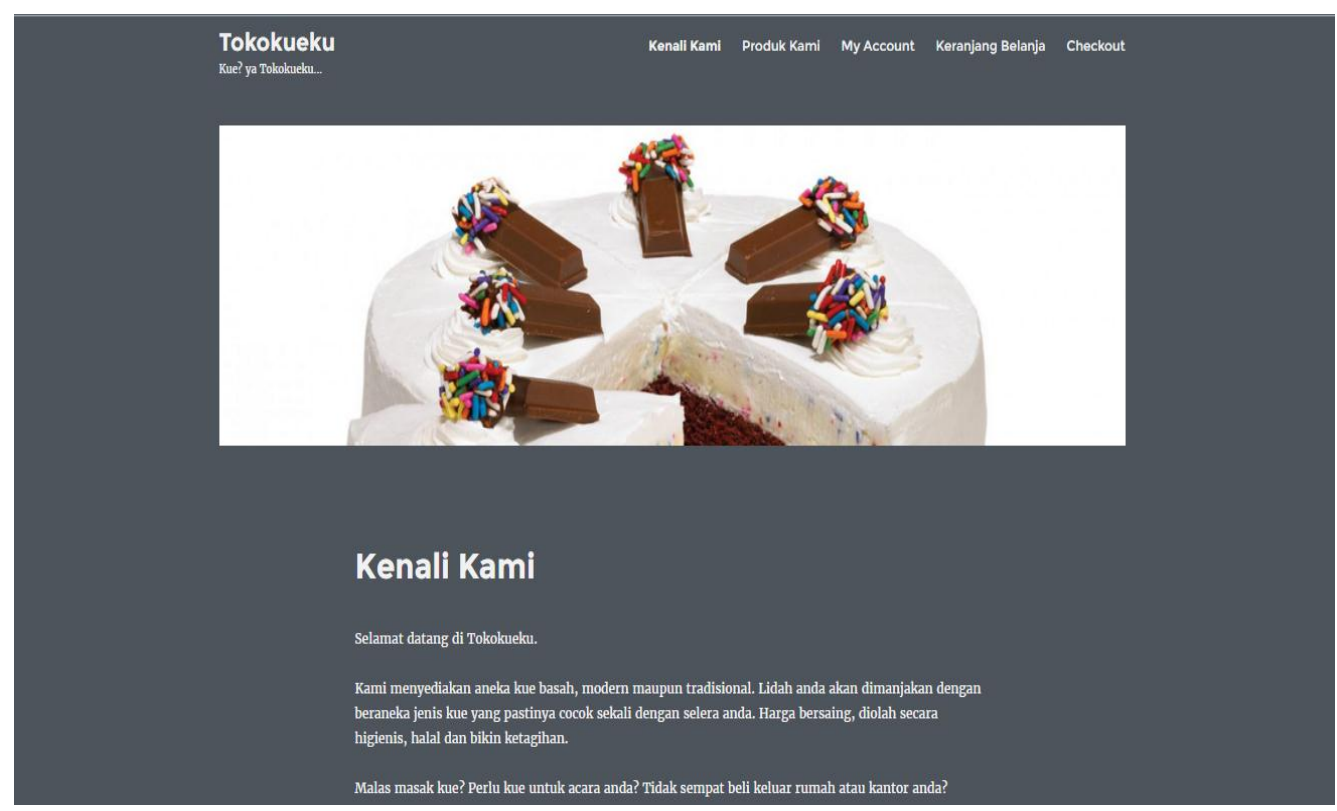

Gambar 10. Jendela Utama Tokokueku

Selain jendela utama, terdapat beberapa form/jendela lain seperti form produk, form kontak dan form testimoni. Disinilah peran masing-masing-masing anggota kelompok berbagi tugas untuk menyelesaikan sejumlah form yang tersedia, tentunya dengan menyesuaikan diri dengan desain standar (desain awal) yang telah disepakati sebelum pembagian tugas.

Namun demikian, dalam penelitian dan pengembangan aplikasi toko kue online dengan menggunakan Subversion dan Redmine PM ini, terdapat hal yang bisa mengganggu keberlangsungan kerja proyek. Hal tersebut, diantarnya, kebebasan dalam menggunakan perintah commit dan update pada Subversion. Sebagai contoh, apabila seorang anggota tim melakukan kesalahan pada task yang dilakukan dan kemudian melakukan proses commit, maka sistem akan menggunakan hasil commit terakhir tersebut, kendati hasilnya ternyata salah. Jadi setiap anggota tim harus berhati-hati dalam melakukan proses commit dan update pada sistem, karena proses ini akan menimpa hasil proses sebelumnya.

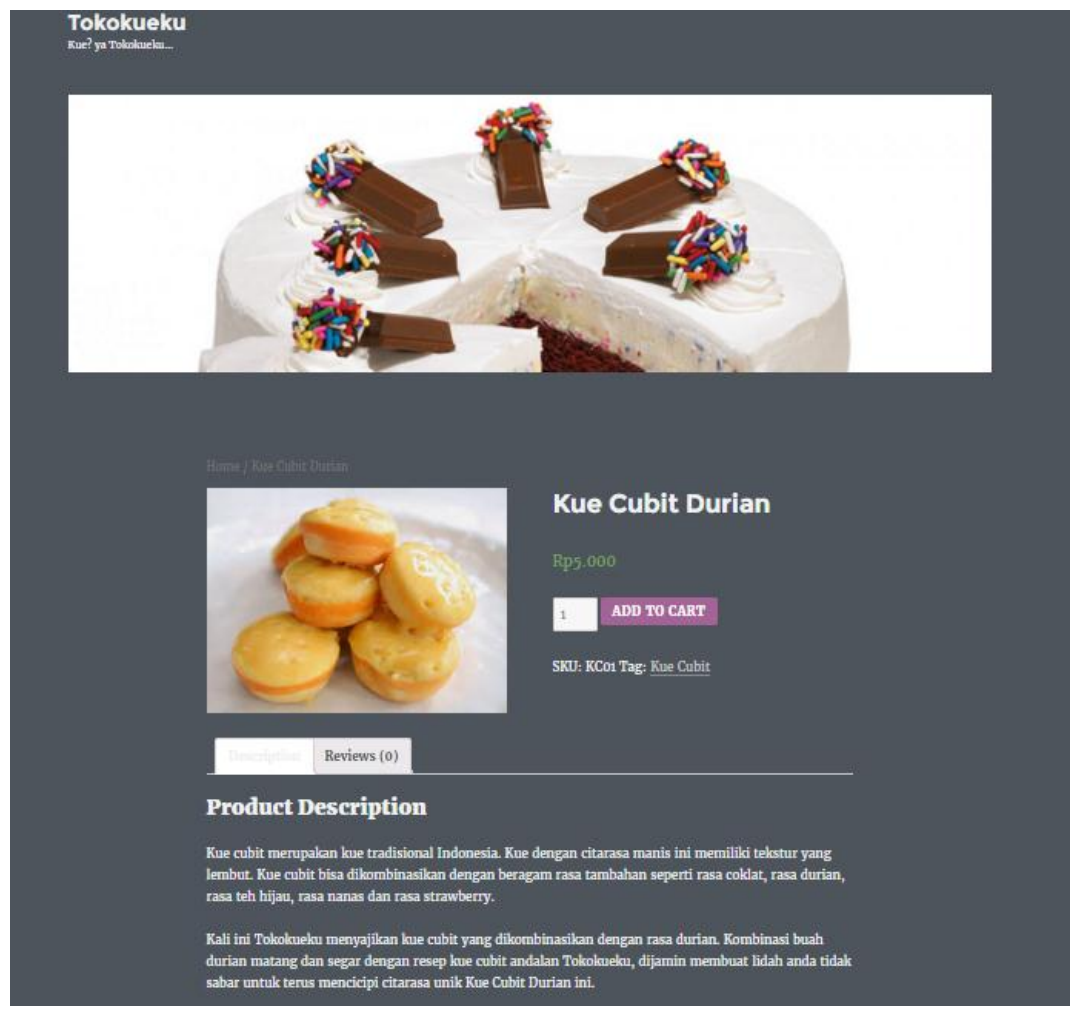

Gambar 10. Salah Satu Menu Website 
Proyek PM yang diatur dengan Redmine PM juga belum sepenuhnya sejalan dengan proyek yang dijalankan dengan Subversion. Karena, Redmine hanya sebatas mengatur pengerjaan dan pengawasan serta pengontrolan proyek saja, tapi tidak bisa mengunci kerja pada Subversion, sehingga apa yang dikerjakan pada Subversion bisa saja mendahului atau bahkan lebih lambat dari yang semestinya diatur oleh Redmine. Disinilah peran sentral seorang PM dalam mengatur, mengawasi dan mengontrol kinerja tim dan proyek.

\section{KESIMPULAN}

Dari hasil penelitian ini dapat ditarik beberapa kesimpulan, yaitu:

a. Web Engineering berbasis team work akan mampu menghasilkan web yang dinamis, atraktif, personal namun dengan proses yang lebih sederhana dan seimbang.

b. Subversion adalah tool yang sangat bermanfaat dalam membangun web secara tim, karena mampu mengontrol dan menyatukan beragam sumber dan platform kedalam sebuah sistem yang utuh.

c. RedmineProject Management adalah sebuah Web-based Project Management yang efisien dan praktis, serta mampu mengatur, mengawasi dan mengontrol kinerja anggota tim serta proyek secara keseluruhan dengan baik.

\section{DAFTAR PUSTAKA}

[1] Brian W. Fitzpatrick., et al., 2008. Version Control with Subversion For Subversion 1.5(Compiled from r3305), Creative Commons, California.

[2] Grace Gata.,et al., 2010. "The Use Of Web-Based Application System Redmine Setting In Project Management", Jurnal ISIT 2010 Universitas BSI Bandung, Bandung.

[3] McRee, Russ., 2013. "Implementing Redmine for Secure Project Management", ISSA Journal April 2013, 38-42, www.issa.org.

[4] Roger S. Pressman., 2001. Software Engineering: A Practitioner's Approach 5th Ed. McGraw-Hill. 